\title{
Pengaruh Stres Kerja Terhadap Kinerja Pegawai pada Kantor Kecamatan Walenrang Utara Kabupaten Luwu
}

\author{
Penulis \\ Raba Nathaniel ${ }^{1}$ \\ Dosen Program Studi Manajemen \\ Universitas Andi Djemma Palopo \\ Email: rabanathaniel@gmail.com

\section{Marsal $^{2}$} \\ Dosen Program Studi Manajemen \\ Universitas Andi Djemma Palopo \\ Email: mkallabe@yahoo.com
}

\author{
Info Artikel \\ p-ISSN : 2615-1871 \\ e-ISSN : 2615-5850 \\ Volume 3 Nomor 1, Maret 2020 \\ DOI: \\ http://dx.doi.org/10.35914/jemma.v3i1.330 \\ Article History: \\ Received, 2 Januari 2020 \\ Revised, 18 Februari 2020 \\ Accepted, 16 Maret 2020
}

\begin{abstract}
ABSTRAK
Berdasarkan hasil pengujian data penelitian diketahui bahwaada pengaruh signifikan stres kerja terhadap kinerja pegawai kantor Kecamatan Walenrang Utara Kabupaten Luwu. Dilihat dari hasil nilai $\mathrm{T}_{\text {hitung }}$ sebesar 7,187> nilai $\mathrm{T}_{\text {tabel }}$ yaitu 2,011 dan signifikansi sebesar $0,000<$ 0,05 , dikuatkan oleh nilai $\mathrm{R}$ Square $\left(\mathrm{R}^{2}\right)$ sebesar 0,534 berarti bahwa variabel stres kerja berpengaruh sebesar 53,4\% terhadap kinerja pegawai pada kantor Kecamatan Walenrang Utara Kabupaten Luwu.
\end{abstract}

Kata Kunci: Stres kerja, dan kinerja Pegawai

\section{PENDAHULUAN}

Masalah yang berkaitan dengan sumber daya manusia merupakan satu hal yang dianggap penting dalam organisasi. Salah satu permasalahan yang umum disetiap organisasi adalah masalah stres kerja. Beberapa penelitian terdahulu terbukti bahwa stres kerja berpengaruh terhadap kinerja SDM. Oleh sebab itu perlu mendapat perhatian dari setiap organisasi agar kinerja sumber daya manusia itu baik dan benar. Stres kerja merupakan suatu kondisi seseorang mengalami ketegangan karena adanya kondisi yang mempengaruhi dirinya. Terdapat tiga sumber stres (stressor) yang mengancam individu yang terdiri dari: 1) stres lingkungan; yaitu adanya ketidakpastian lingkungan mempengaruhi desain dari struktur organisasi, ketidakpastian itu juga memempengaruhi tingkat stres dikalangan para karyawan dalam organisasi tersebut. 2) Stres organisasi; yaitu tekanan untuk menghindari kekeliruan atau menyelesaikan tugas dalam suatu kurun waktu yang terbatas, beban kerja yang berlebihan, seorang pemimpin yang menuntut dan tidak peka, serta rekan kerja yang tidak menyenangkan. 3) Stres individual; yaitu mencakup faktor-faktor dalam kehidupan pribadi karyawan, terutama masalah keluarga, masalah ekonomi pribadi, dan karakteristik kepribadian yang inheren. Stres kerja dapat menimbulkan dampak positif maupun negatif, oleh karena itu yang harus dilakukan bukanlah menghilangkan seluruh stres tetapi membatasi dampak negatif dari stres kerja tersebut. 
Penelitian ini dilakukan di Kantor kecamatan Walenrang Utara Kabupaten Luwu yang merupakan suatu organisasi yang berfokus kepada pelayanan masyarakat yang ada di Kecamatan Walenrang Utara. Menurut salah seeorang pegawai kantor kecamatan Walenrang Utara menyatakan bahwa dirinya pernah mengalami stres kerja karena double job dan tuntutan tugas yang banyak harus terselesaikan dalam jangka waktu tertentu dan butuh waktu beradaptasi pada pekerjaan. Kegiatan yang dilakukan pegawai yang ada di kantor kecamatan Walenrang Utara adalah melayani segala kebutuhan masyarakat dibidang pemerintahan. Kantor kecamatanWalenrang Utara sangat membutuhkan kinerja pegawai yang tinggi untuk meningkatkan kinerja pelayanan, karena dengan memiliki tanggung jawab yang tinggi, tujuan yang realistis, rencana kerja yang menyeluruh, berani mengambil risiko yang dihadapi, maka kinerja pegawai akan meningkat. Oleh karena itu salah satu cara adalah dengan meminimalisir stres kerja dan menciptakan lingkungan kerja yang baik dan kondusif. Adapun tujuan penelitian yaitu untuk mengetahui Pengaruh Stres Kerja terhadap Kinerja Pegawai pada Kantor Kecamatan Walenrang Utara Kabupaten Luwu.

\section{METODE PENELITIAN}

Lokasi dan objek penelitian di Kantor Kecamatan Walenrang Utara Kabupaten Luwu. Waktu yang dipergunakan dalam penelitian kurang lebih 6 bulan, mulai bulan Maret sampai bulan Agustus 2019. Proses pengumpulan data yang diperlukan dalam pembahasan ini melalui dua tahap penelitian, yaitu:

1. Teknik dokumentasi

Metode pengumpulan data yang digunakan untuk menulusuri data historis yang tersedia dalam bentuk surat-surat, catatan harian, laporan-laporan tertulis

2. Teknik wawancara

Teknik pengumpulan data dengan malakukan tanya jawab dengan pihak yang berwenang dalam memberikan data yang dibutuhkan.

3. Angket atau Kuesioner

Angket atau kuesioner adalah teknik pengumpulan data melalui kusioner yang berisi pertanyaan-pertanyaan yang diajukan secara tertulis pada responden.

Adapun jenis data yang digunakan dalam penelitian iniadalah:

1. Data Kualitatif adalah data yang bukan dalam bentuk angka-angka atau tidak dapat dihitung, dan diperoleh dari hasil wawancara dengan pimpinan dan pegawai kantor kecamatan Walenrang Utara serta informasi-informasi yang diperoleh dari pihak lain yang berkaitan dengan masalah yang diteliti.

2. Data Kuantitatif adalah data yang diperoleh dalam bentuk angka-angka yang dapat dihitung, yang diperoleh dari kuesioner yang dibagikan dan berhubungan dengan masalah yang diteliti.

\section{Populasi dan Sampel Penelitian}

1. Populasi

Dalam penelitian inipopulasi adalah seluruh pegawai di Kantor Kecamatan Walenrang Utara Kabupaten Luwu yaitu sebanyak 47 orang, yang terdiri dari pimpinan dan pegawai

2. Sampel

Sampel yang digunakan dalam penelitian ini adalah seluruh pegawai pada Kantor Kecamatan Walenrang Utara Kabupaten Luwu yaitu sebanyak 47 orang, yang selanjutnya disebut sampel jenuh.

\section{Metode Analisis Data}

Untuk membuktikan hipotesis yang telah dikemukakan maka dalam penelitian ini digunakan : 


\section{Analisis Deskriptif Kuantitatif}

Analisis deskriptif kuantitatif merupakan metode yang bertujuan mengubah kumpulan data mentah menjadi bentuk yang mudah dipahami, dalam bentuk informasi yang ringkas, dimana hasil penelitian beserta analisisnya diuraikan dalam suatu tulisan ilmiah yang mana dari analisis tersebut akan dibentuk suatu simpulan.

Dalam pengukuran jawaban responden, pengisian kuesioner kemanfaatan dan kemudahan penggunaan teknologi informasi terhadap kinerja pegawai diukur dengan menggunakan skala likert, dengan tingkatan sebagai berikut :

1. Jawaban Sangat Setuju

diberi bobot 5

2. Jawaban Setuju

diberi bobot 4

3. Jawaban Ragu-ragu

diberi bobot 3

4. Jawaban Tidak Setuju

diberi bobot 2

5. Jawaban Sangat Tidak Setuju

diberi bobot 1

Instrumen penelitian (kuisioner) yang baik harus memenuhi persyaratan yaitu valid dan reliabel. Mengetahui validitas dan reliabilitas kuesioner perlu dilakukan pengujian atas kuisioner dengan menggunakan uji validitas dan uji reliabilitas, validitas dan reliabilitas ini bertujuan untuk menguji apakah kuesioner yang disebarkan untuk mendapatkan data penelitian adalah valid dan reliabel, maka untuk itu, penulis juga akan melakukan kedua uji ini terhadap instrumen penelitian (kuisioner).

2. Uji validitas dan Reabilitas

a. Uji T (Uji Parsial)

Uji ini digunakan untuk mengetahui apakah masing-masing variabel bebasnya secara sendiri-sendiri berpengaruh secara signifikan terhadap variabel terikatnya. Dimana $\mathrm{T}_{\text {tabel }}>\mathrm{T}_{\text {hitung, }} \mathrm{H} 0$ diterima. Dan jika $\mathrm{T}_{\text {tabel }}<\mathrm{T}_{\text {hitung, }}$ maka $\mathrm{H} 1$ diterima, begitupun jika sig $>\alpha ́(0,05)$, maka H0 diterima H1 ditolak dan jika sig < ́ $(0,05)$, maka H0 ditolak H1 diterima.

b. Uji Korelasi (R)

Pengukuran statistik kovarian atau asosiasi antara dua variabel. Besarnya koefisien korelasi berkisar antara +1 sampai dengan -1 . Koefisien korelasi menunjukkan kekuatan hubungan linier dan arah hubuangn dua variabel acak. Jika koefisien korelasi positif, maka kedua variabel mempunyai hubungan searah. Artinya jika nilai X tinggi, maka nilaia variabel Y akan tinggi pula.

3. Analisis Kuantitatif

Dalam mengetahui hubungan dan pengaruh antara kemanfaatan dan kemudahan penggunaan teknologi informasi dengan produktivitas pegawai digunakan teknik analisis regresi sederhana, untuk mengetahui besarnya pengaruh secara kuantitatif dari suatu perubahan (variabel X) terhadap kejadian lainnya (variabel Y). Analisis regresi menggunakan rumus persamaan regresi sederhana seperti yang dikutip dalam Sugiyono (2008: 277), yaitu :

$$
\mathrm{Y}=\mathrm{a}+\mathrm{bx}+\mathrm{e}
$$

Dimana :

$$
\begin{aligned}
& \mathrm{Y}=\text { Stres Kerja } \\
& \mathrm{X}=\text { Kinerja Pegawai } \\
& \mathrm{A}=\text { Konstanta } \\
& \mathrm{b}=\text { koefisien regresi parsial, mengukur rata-rata nilai } \mathrm{Y} \text { untuk tiap perubahan } \mathrm{x} . \\
& \mathrm{e}=\text { Error }
\end{aligned}
$$




\section{HASIL DAN PEMBAHASAN}

\section{Deskripsi Responden}

Deskripsi responden menguraikan atau menggambarkan indentitas responden yang dijadikan sebagai sampel dalam penelitian. Dalam penelitian ini responden ditetapkan sebanyak 47 orang yang merupakan pegawai tetap dan tenaga honorer pada Kantor Kecamatan Walenrang Utara Kabupaten Luwu.

Gambaran tentang identitas responden dalam penelitian ini ditekankan berdasarkan jenis kelamin, usia, tingkat pendidikan terakhir dan lamanya bekerja sebagai pegawai pada Kantor Kecamatan Walenrang Utara Kabupaten Luwu.

\section{a. Deskripsi Responden Berdasarkan Jenis Kelamin}

Untuk mengetahui deskripsi responden berdasarkan jenis kelamin, dapat kita lihat pada Tabel 1 berikut:

Tabel 1 Deskripsi Responden Berdasarkan Jenis Kelamin

\begin{tabular}{|c|c|c|c|}
\hline No. & Jenis Kelamin & Jumlah & Persentase \\
\hline 1 & Laki-laki & 15 & $32 \%$ \\
\hline 2 & Perempuan & 32 & $68 \%$ \\
\hline \multicolumn{2}{|c|}{ Jumlah } & 47 & $100 \%$ \\
\hline
\end{tabular}

Sumber: Data Primer, 2019

Dari Tabel 1 tentang deskripsi responden berdasarkan jenis kelamin dapat dilihat bahwa dari keseluruhan responden yang berjumlah 47 orang terdapat 15 orang atau sekitar $32 \%$ yang berjenis kelamin laki-laki dan sebanyak 32 orang atau $68 \%$ yang berjenis kelamin perempuan. Hal ini menunjukkan bahwa pegawai pada Kantor Kecamatan Walenrang Utara Kabupaten Luwu didominasi oleh perempuan.

\section{b. Deskripsi Responden Berdasarkan Usia}

Untuk mengetahui deskripsi responden berdasarkan usia, dapat kita lihat pada Tabel 2 berikut:

Tabel 2 Deskripsi Responden Berdasarkan Usia

\begin{tabular}{|c|c|c|c|}
\hline No. & Usia & Jumlah & Persentase \\
\hline 1 & $25-30$ Tahun & 12 & $25,53 \%$ \\
\hline 2 & $31-35$ Tahun & 18 & $38,30 \%$ \\
\hline 3 & $36-40$ Tahun & 13 & $27,66 \%$ \\
\hline 4 & Di atas 40 Tahun & 4 & $8,51 \%$ \\
\hline \multicolumn{2}{|c|}{ Jumlah Responden } & 47 & $100 \%$ \\
\hline
\end{tabular}

Sumber: Data Primer, 2019

Dari Tabel 2 tentang deskripsi responden berdasarkan usia, bahwa dari keseluruhan responden yang berjumlah 47 orang terdapat 12 orang atau $25,53 \%$ yang berusia $25-30$ tahun, 18 orang atau 38,30\% yang berusia $31-35$ tahun, 13 orang atau 27,66\% yang berusia $36-40$ tahun dan sisanya sebanyak 4 orang atau $8,51 \%$ yang berusia di atas 40 tahun. Hal tersebut menunjukkan bahwa pegawai pada Kantor Kecamatan Walenrang Utara Kabupaten Luwu masih berusia produktif sehingga mampu bekerja dengan maksimal demi kemajuan instansi.

\section{c. Deskripsi Responden Berdasarkan Tingkat Pendidikan Terakhir}

Untuk mengetahui deskripsi responden berdasarkan tingkat pendidikan terakhir yang pernah dilalui responden, dapat kita lihat pada Tabel 3 berikut: 
Tabel 3 Deskripsi Responden Berdasarkan Tingkat Pendidikan Terakhir

\begin{tabular}{|c|c|c|c|}
\hline No. & Pendidikan & Jumlah & Persentase \\
\hline 1 & SMA & 6 & $12,77 \%$ \\
\hline 2 & D3 & 19 & $40,43 \%$ \\
\hline 3 & S1/S2 & 22 & $46,81 \%$ \\
\hline \multicolumn{2}{|c|}{ Jumlah Responden } & 47 & $100 \%$ \\
\hline
\end{tabular}

Sumber: Data Primer, 2019

Dari Tabel 3 tentang deskripsi responden berdasarkan tingkat pendidikan bahwa dari keseluruhan responden yang berjumlah 47 orang terdapat 6 orang atau 12,77\% yang berpendidikan SMA, 19 orang atau 40,43\% yang berpendidikan D3 dan sisanya sebanyak 22 orang atau 46,81\% yang berpendidikan S1/S2. Data tersebut menunjukkan bahwa pegawai pada Kantor Kecamatan Walenrang Utara Kabupaten Luwu sebagian besar menyelesaikan pendidikan S1/S2, menunjukkan bahwa jenjang pendidikan mempengaruhi kualitas kerja.

\section{d. Deskripsi Responden Berdasarkan Lamanya Bekerja}

Untuk mengetahui deskripsi responden berdasarkan lamanya bekerja pada instansi, dapat kita lihat pada Tabel 4 berikut:

Tabel 4. Deskripsi Responden Berdasarkan Lamanya Bekerja

\begin{tabular}{|c|c|c|c|}
\hline No. & Lama Bekerja & Jumlah & Persentase \\
\hline 1 & $5-6$ Tahun & 12 & 25,53 \\
\hline 2 & $7-10$ Tahun & 29 & 61,70 \\
\hline 3 & Di atas 10 Tahun & 6 & 12,77 \\
\hline & Jumlah Responden & 47 & 100 \\
\hline
\end{tabular}

Sumber: Data Primer, 2019

Dari Tabel 4 tentang deskripsi responden berdasarkan lamanya bekerja dapat dilihat bahwa dari keseluruhan responden yang berjumlah 47 orang terdapat 12 orang atau 25,53\% yang sudah bekerja selama $5-6$ tahun, 29 orang atau $61,70 \%$ yang sudah bekerja selama $7-$ 10 tahun dan 6 orang atau $12,77 \%$ yang sudah bekerja sebagai karyawan di atas 10 tahun lebih. Hal tersebut menunjukkan bahwa pegawai pada Kantor Kecamatan Walenrang Utara Kabupaten Luwu rata-rata telah memiliki pengalaman kerja yang tinggi. Hal tersebut sangat baik bagi instansi pemerintahan karena dengan pengalaman kerja yang tinggi membuat para pegawai akan lebih terampil dan profesional dalam melaksanakan tugas.

\section{Penetapan Jangkauan (Range)}

Survey ini menggunakan skala liker dengan bobot tertinggi ditiap pernyataan adalah 5 dan bobot terendah 1. Dengan jumlah responden sebanyak 47 orang, maka:

Range $=\frac{\text { Skor Tertinggi-Skor Terendah }}{\text { Range }}$

Skor Tertinggi : 5

Skor Terendah : 1

Sehingga range untuk hasil survey $: \frac{5-1}{5}=0,8$

Range skor :

$1,00-1,80=$ Sangat Rendah

$1,90-2,60=$ Rendah

$2,70-3,40=$ Cukup Tinggi

$3,50-4,20=$ Tinggi

$4,30-5,00=$ Sangat Tinggi 


\section{Deskripsi Variabel Penelitian}

Deskripsi variabel penelitian adalah hasil penelitian yang menjelaskan pengaruh stres kerja, berdasarkan tanggapan pengguna responden dalam memberikan informasi terhadap pernyataan kuesioner yang diajukan sesuai pemahaman responden. Variabel (X) adalah stres kerja terhadap kinerja pegawai sebagai variabel terkait (Y) dijelaskan di bawah ini :

a. Deskripsi Variabel Stres kerja

Stres kerja adalah kemampuan dan kemauan untuk menyelaraskan perilaku pribadi dengan kebutuhan, prioritas dan tujuan organisasi. Stres kerja mempunyai 5 indikator yaitu tuntutan tugas, tuntutan peran, tuntutan antar pribadi, struktur organisasi dan kepemimpinan organisasi. Untuk lebih jelasnya dapat dilihat pada tabel 5 frekuensi dan persentase tanggapan responden sebagai berikut:

Tabel 5. Frekuensi dan Persentase Tanggapan Responden Mengenai Indikator Tuntutan Tugas

\begin{tabular}{|c|c|c|c|c|c|c|c|c|c|}
\hline \multirow[b]{2}{*}{ NO } & \multirow[b]{2}{*}{ Tuntutan Tugas } & \multicolumn{5}{|c|}{ Jawaban } & \multirow[b]{2}{*}{ Skor } & \multirow{2}{*}{$\begin{array}{l}\text { Rata- } \\
\text { rata } \\
\text { skor }\end{array}$} & \multirow[b]{2}{*}{ Ket. } \\
\hline & & $\begin{array}{l}\text { STS } \\
\text { (1) }\end{array}$ & $\begin{array}{l}\text { TS } \\
\text { (2) }\end{array}$ & $\begin{array}{l}\mathbf{R r} \\
\text { (3) }\end{array}$ & $\begin{array}{c}S \\
(4)\end{array}$ & $\begin{array}{l}\text { SS } \\
\text { (5) }\end{array}$ & & & \\
\hline 1 & $\begin{array}{lcr}\begin{array}{l}\text { Target } \\
\text { tuntutan }\end{array} & \text { instansi } & \text { dan } \\
\text { tinggi. } & & \text { terlalu } \\
\end{array}$ & 0 & 0 & 2 & 21 & 24 & 210 & 4,47 & $\begin{array}{l}\text { Sangat } \\
\text { Tinggi }\end{array}$ \\
\hline 2 & $\begin{array}{l}\text { Semakin banyak tuntutan } \\
\text { tugas maka semakin tinggi } \\
\text { tekanan yang dirasakan } \\
\text { pegawai. }\end{array}$ & 0 & 1 & 0 & 21 & 25 & 211 & 4,49 & $\begin{array}{l}\text { Sangat } \\
\text { Tinggi }\end{array}$ \\
\hline 3 & $\begin{array}{l}\text { Tuntutan pekerjaan untuk } \\
\text { bekerja dengan cepat } \\
\text { sering mengakibatkan } \\
\text { kesalahan kerja. }\end{array}$ & 0 & 2 & 3 & 19 & 23 & 204 & 4,34 & $\begin{array}{l}\text { Sangat } \\
\text { Tinggi }\end{array}$ \\
\hline \multicolumn{7}{|c|}{ Jumlah } & 625 & 13,30 & \\
\hline \multicolumn{8}{|c|}{ Rata-rata } & 4,43 & $\begin{array}{l}\text { Sangat } \\
\text { Tinggi }\end{array}$ \\
\hline
\end{tabular}

Sumber : Data diolah (2019)

Dari Tabel 5 di atas, dapat diketahui bahwa persepsi responden terhadap variabel penlilaian kinerja mengenai indikator tuntutan tugas dengan pernyataan tertinggi yaitu pernyataan nomor 2 dengan jumlah skor 211 dan presentase $4,49 \%$ berada pada range skor sangat tinggi, karena semakin banyak tuntutan tugas maka semakin tinggi tekanan yang dirasakan pegawai. Untuk rata-rata skornya sebesar $4,43 \%$ dan berada pada range skor sangat tinggi.

Tabel 6. Frekuensi Dan Persentase Tanggapan Responden Mengenai Indikator Tuntutan Peran

\begin{tabular}{|c|c|c|c|c|c|c|c|c|c|}
\hline \multirow[b]{2}{*}{ NO } & \multirow[b]{2}{*}{ Tuntutan Peran } & \multicolumn{5}{|c|}{ Jawaban } & \multirow[b]{2}{*}{ Skor } & \multirow{2}{*}{$\begin{array}{l}\text { Rata- } \\
\text { rata } \\
\text { skor }\end{array}$} & \multirow[b]{2}{*}{ Ket. } \\
\hline & & $\begin{array}{c}\text { STS } \\
\text { (1) }\end{array}$ & $\begin{array}{l}\text { TS } \\
\text { (2) }\end{array}$ & $\begin{array}{l}\mathbf{R r} \\
\text { (3) }\end{array}$ & $\begin{array}{c}S \\
(4)\end{array}$ & $\begin{array}{l}\text { SS } \\
\text { (5) }\end{array}$ & & & \\
\hline 1 & $\begin{array}{l}\text { Peran yang diterima sering } \\
\text { bertentangan dengan satu } \\
\text { sama lain. }\end{array}$ & 0 & 0 & 6 & 30 & 11 & 193 & 4,11 & Tinggi \\
\hline 2 & $\begin{array}{l}\text { Pekerjaan yang sangat sulit } \\
\text { membuat pegawai mudah } \\
\text { tersinggung. }\end{array}$ & 0 & 1 & 4 & 35 & 7 & 187 & 3,98 & Tinggi \\
\hline
\end{tabular}




\begin{tabular}{|c|l|l|l|l|l|l|l|l|l|}
\hline 3 & $\begin{array}{l}\text { Kurang baiknya interaksi } \\
\text { antara sesama rekan kerja } \\
\text { membuat pegawai mudah } \\
\text { tersinggung }\end{array}$ & 0 & 0 & 6 & 24 & 17 & 199 & 4,23 & $\begin{array}{c}\text { Sangat } \\
\text { Tinggi }\end{array}$ \\
\hline \multicolumn{1}{|c|}{ Jumlah } \\
\hline
\end{tabular}

Sumber : Data diolah (2019)

Dari Tabel 6 di atas, dapat diketahui bahwa persepsi responden terhadap variabel penlilaian kinerja mengenai indikator tuntutan peran dengan pernyataan tertinggi yaitu pernyataan nomor 3 dengan jumlah skor 199 dan presentase 4,23\% berada pada range skor sangat tinggi, karena kurang baiknya interaksi antara sesama rekan kerja membuat pegawai mudah tersinggung.Untuk rata-rata skornya sebesar $4,11 \%$ dan berada pada range skor tinggi.

Tabel 7. Frekuensi Dan Persentase Tanggapan Responden Mengenai Indikator Tuntutan Antarpribadi

\begin{tabular}{|c|c|c|c|c|c|c|c|c|c|}
\hline \multirow[b]{2}{*}{ NO } & \multirow[b]{2}{*}{ Tuntutan Antarpribadi } & \multicolumn{5}{|c|}{ Jawaban } & \multirow[b]{2}{*}{ Skor } & \multirow{2}{*}{$\begin{array}{l}\text { Rata- } \\
\text { rata } \\
\text { skor }\end{array}$} & \multirow[b]{2}{*}{ Ket. } \\
\hline & & $\begin{array}{l}\text { STS } \\
\text { (1) }\end{array}$ & $\begin{array}{l}\text { TS } \\
\text { (2) }\end{array}$ & $\begin{array}{l}\text { Rr } \\
\text { (3) }\end{array}$ & $\begin{array}{c}S \\
\text { (4) }\end{array}$ & $\begin{array}{l}\text { SS } \\
\text { (5) }\end{array}$ & & & \\
\hline 1 & $\begin{array}{l}\text { Keberhasilan pegawai lain } \\
\text { menjadi pesaing kinerja } \\
\text { Pegawai. }\end{array}$ & 0 & 3 & 10 & 18 & 16 & 198 & 4,21 & $\begin{array}{l}\text { Sangat } \\
\text { Tinggi }\end{array}$ \\
\hline 2 & 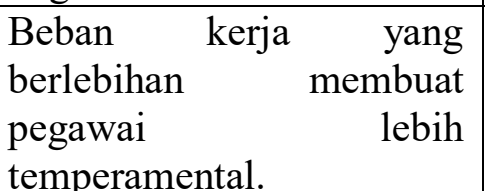 & 0 & 13 & 8 & 18 & 7 & 157 & 3,34 & $\begin{array}{l}\text { Sangat } \\
\text { Tinggi }\end{array}$ \\
\hline 3 & $\begin{array}{l}\text { Pegawai mudah cemas } \\
\text { apabila pekerjaan yang } \\
\text { dilakukan belum selesai. }\end{array}$ & 0 & 3 & 6 & 26 & 12 & 188 & 4,00 & $\begin{array}{l}\text { Sangat } \\
\text { Tinggi }\end{array}$ \\
\hline \multicolumn{7}{|c|}{$\begin{array}{ll}\text { Jumlah } \\
\end{array}$} & 539 & 11,47 & \\
\hline \multicolumn{7}{|c|}{ Rata-rata } & & 3,82 & Tinggi \\
\hline
\end{tabular}

Sumber : Data diolah (2019)

Dari Tabel $7 \mathrm{di}$ atas, dapat diketahui bahwa persepsi responden terhadap variabel penlilaian kinerja mengenai indikator tuntutan antarpribadi dengan pernyataan tertinggi yaitu pernyataan nomor 1 dengan jumlah skor 198 dan presentase 4,21\% berada pada range skor sangat tinggi, karena keberhasilan pegawai lain menjadi pesaing kinerja Pegawai. Untuk ratarata skornya sebesar 3,82\% dan berada pada range skor tinggi.

Tabel 8. Frekuensi Dan Persentase Tanggapan Responden Mengenai Indikator Struktur Organisasi

\begin{tabular}{|c|c|c|c|c|c|c|c|c|c|}
\hline \multirow[b]{2}{*}{ NO } & \multirow[b]{2}{*}{ Struktur Organisasi } & \multicolumn{5}{|c|}{ Jawaban } & \multirow[b]{2}{*}{ Skor } & \multirow{2}{*}{$\begin{array}{l}\text { Rata- } \\
\text { rata } \\
\text { skor }\end{array}$} & \multirow[b]{2}{*}{ Ket. } \\
\hline & & $\begin{array}{l}\text { STS } \\
\text { (1) }\end{array}$ & $\begin{array}{l}\text { TS } \\
\text { (2) }\end{array}$ & $\begin{array}{l}\mathbf{R r} \\
\text { (3) }\end{array}$ & $\begin{array}{c}S \\
(4)\end{array}$ & $\begin{array}{l}\text { SS } \\
\text { (5) }\end{array}$ & & & \\
\hline 1 & $\begin{array}{l}\text { Alur perintah struktur } \\
\text { organisasi yang tumpang } \\
\text { tindih } \\
\text { keidaknyamanan pegawai. }\end{array}$ & 0 & 0 & 4 & 29 & 14 & 200 & 4,25 & $\begin{array}{l}\text { Sangat } \\
\text { Tinggi }\end{array}$ \\
\hline 2 & $\begin{array}{lrr}\text { Segalanya harus diminta } \\
\text { persetujuan } & \text { atasan } \\
\text { sehingga } & \text { tidak }\end{array}$ & 0 & 2 & 9 & 22 & 14 & 189 & 4,02 & Tinggi \\
\hline
\end{tabular}




\begin{tabular}{|c|l|l|l|l|l|l|l|l|l|}
\hline & $\begin{array}{l}\text { kesempatan bagi pegawai } \\
\text { untuk berpartisipasi dalam } \\
\text { mencapai tujuan } \\
\text { organisasi. }\end{array}$ & & & & & & & \\
\hline 3 & $\begin{array}{l}\text { Kurang baik struktur } \\
\text { organisasi akan } \\
\text { menghambat pencapaian } \\
\text { target organisasi. } 0\end{array}$ & 1 & 0 & 21 & 25 & 211 & 4,49 & $\begin{array}{r}\text { Sangat } \\
\text { Tinggi }\end{array}$ \\
\hline \\
Rumlah \\
Rata-rata
\end{tabular}

Sumber : Data diolah (2019)

Dari Tabel 8 di atas, dapat diketahui bahwa persepsi responden terhadap variabel penlilaian kinerja mengenai indikator struktur organisasi dengan pernyataan tertinggi yaitu pernyataan nomor 3 dengan jumlah skor 211 dan presentase 4,49\% berada pada range skor sangat tinggi, karena kurang baik struktur organisasi akan menghambat pencapaian target organisasi. Untuk rata-rata skornya sebesar $4,25 \%$ dan berada pada range skor sangat tinggi.

Tabel 9. Frekuensi Dan Persentase Tanggapan Responden Mengenai Indikator Kepemimpinan Organisasi

\begin{tabular}{|c|c|c|c|c|c|c|c|c|c|}
\hline \multirow[b]{2}{*}{ NO } & \multirow[b]{2}{*}{$\begin{array}{l}\text { Kepemimpinan } \\
\text { Organisasi }\end{array}$} & \multicolumn{5}{|c|}{ Jawaban } & \multirow[b]{2}{*}{ Skor } & \multirow{2}{*}{$\begin{array}{l}\text { Rata- } \\
\text { rata } \\
\text { skor }\end{array}$} & \multirow[b]{2}{*}{ Ket. } \\
\hline & & $\begin{array}{c}\text { STS } \\
\text { (1) }\end{array}$ & $\begin{array}{l}\text { TS } \\
\text { (2) }\end{array}$ & $\begin{array}{l}\text { Rr } \\
\text { (3) }\end{array}$ & $\begin{array}{c}S \\
(4)\end{array}$ & $\begin{array}{l}\text { SS } \\
\text { (5) }\end{array}$ & & & \\
\hline 1 & $\begin{array}{l}\text { Sikap pimpinan dan } \\
\text { tekanan kerja menjadi } \\
\text { iklim dalam kantor relatif } \\
\text { tidak kondusif }\end{array}$ & 0 & 7 & 3 & 24 & 13 & 184 & 3,91 & Tinggi \\
\hline 2 & $\begin{array}{l}\text { Kurang baiknya hubungan } \\
\text { antara pimpinan dan } \\
\text { bawahan membuat suasana } \\
\text { kerja kurang kondusif }\end{array}$ & 0 & 4 & 1 & 24 & 18 & 197 & 4,19 & Tinggi \\
\hline 3 & $\begin{array}{l}\text { Pimpinan selalu menerima } \\
\text { masukan dari bawahannya. }\end{array}$ & 2 & 5 & 7 & 22 & 11 & 176 & 3,74 & Tinggi \\
\hline \multicolumn{7}{|c|}{ Jumlah } & 557 & 11,85 & \\
\hline \multicolumn{7}{|c|}{ Rata-rata } & & 3,95 & Tinggi \\
\hline
\end{tabular}

Sumber : Data diolah (2019)

Dari Tabel 9 di atas, dapat diketahui bahwa persepsi responden terhadap variabel penlilaian kinerja mengenai indikator kepemimpinan oraganisasi dengan pernyataan tertinggi yaitu pernyataan nomor 2 dengan jumlah skor 197 dan presentase $4,19 \%$ berada pada range skor tinggi, karena kurang baiknya hubungan antara pimpinan dan bawahan membuat suasana kerja kurang kondusif. Untuk rata-rata skornya sebesar 3,95\% dan berada pada range skor tinggi.

Tabel 10. Kesimpulan Rata-Rata Tanggapan Responden Terhadap Variabel dari Stres kerja.

\begin{tabular}{|c|l|c|c|c|}
\hline No & \multicolumn{1}{|c|}{ Indikator } & Jumlah Skor & Rata-Rata & Ket \\
\hline 1 & Tuntutan Tugas & 625 & 4,43 & Sangat Tinggi \\
\hline 2 & Tuntutan Peran & 579 & 4,11 & Tinggi \\
\hline 3 & Tuntutan Antarpribadi & 539 & 3,82 & Tinggi \\
\hline 4 & Struktur Organisasi & 600 & 4,25 & Sangat Tinggi \\
\hline
\end{tabular}




\begin{tabular}{|c|l|c|c|c|}
\hline 5 & Kepemimpinan Organisasi & 557 & 3,95 & Tinggi \\
\hline
\end{tabular}

Sumber : Data diolah (2019)

Berdasarkan tabel 10 kesimpulan rata-rata tanggapan responden terhadap indikator dari stres kerja diatas dapat dilihat bahwa indikator dengan jumlah skor tertinggi 625 berdasarkan jawaban responden adalah tuntutan tugas dengan rata-rata skor 4,43. Hal tersebut menunjukan bahwa indikator tuntutan tugas memiliki pengaruh yang kuat dalam hal mempengaruhi kinerja pegawai kantor Kecamatan Walenrang Utara Kabupaten Luwu. Pada tabel diatas juga dapat dilihat variabel dari stres kerja mengenai indikator dengan jumlah skor terendah yaitu tuntutan antarpribadi dengan jumlah skor 539 dengan rata-rata 3,82, hal ini menunjukkan bahwa tuntutan antarpribadi yang dimiliki oleh pegawai kantor Kecamatan Walenrang Utara Kabupaten Luwu perlu ditingkatkan lagi.

\section{b. Deskripsi Variabel Kinerja Pegawai}

Kinerja pegawai adalah kesediaan seseorang atau kelompok orang untuk melakukan sesuatu kegiatan dan menyempurnakannya sesuai dengan tanggung jawab dengan hasil seperti yang diharapkan. Kinerja mempunyai 4 indikator yaitu efektivitas, tanggung jawab, disiplin, dan inisiatif. Lebih jelasnya dapat dilihat pada tanggapan responden mengenai kinerja pegawai sebagai berikut :

Tabel 11. Frekuensi dan Persentase Tanggapan Responden Mengenai Indikator Efektivitas

\begin{tabular}{|c|c|c|c|c|c|c|c|c|c|}
\hline \multirow{3}{*}{ NO } & \multirow[b]{3}{*}{ Efektivitas } & \multirow{2}{*}{\multicolumn{5}{|c|}{ Jawaban }} & \multirow[b]{3}{*}{ Skor } & \multirow{3}{*}{$\begin{array}{l}\text { Rata- } \\
\text { rata } \\
\text { skor }\end{array}$} & \multirow[b]{3}{*}{ Ket. } \\
\hline & & & & & & & & & \\
\hline & & $\begin{array}{c}\text { STS } \\
\text { (1) }\end{array}$ & $\begin{array}{l}\text { TS } \\
\text { (2) }\end{array}$ & $\begin{array}{l}\mathbf{R r} \\
\text { (3) }\end{array}$ & $\begin{array}{c}S \\
(4)\end{array}$ & $\begin{array}{l}\text { SS } \\
\text { (5) }\end{array}$ & & & \\
\hline 1 & $\begin{array}{l}\text { Pegawai selalu bekerja } \\
\text { dengan disiplin yang } \\
\text { tinggi demi tercapainya } \\
\text { tujuan perusahaan. }\end{array}$ & 0 & 2 & 9 & 22 & 14 & 189 & 4,02 & Tinggi \\
\hline 2 & $\begin{array}{l}\text { Masyarakat } \text { sangat puas } \\
\text { atas keefektifan pegawai } \\
\text { dalam } \\
\text { pekerjaan. }\end{array}$ & 0 & 2 & 10 & 24 & 11 & 185 & 3,93 & Tinggi \\
\hline 3 & $\begin{array}{l}\text { Pegawai telah melakukan } \\
\text { pekerjaan yang benar } \\
\text { dalam } \\
\text { konsumen. }\end{array}$ & 0 & 4 & 7 & 24 & 12 & 191 & 4,06 & Tinggi \\
\hline \multicolumn{7}{|c|}{ Jumlah } & 565 & 12,02 & \\
\hline \multicolumn{7}{|c|}{ Rata-rata } & & 4,01 & Tinggi \\
\hline
\end{tabular}

Sumber : Data diolah (2019)

Dari Tabel 11 di atas, dapat diketahui bahwa persepsi responden terhadap variabel kinerja pegawai mengenai indikator efektivitas dengan pernyataan tertinggi yaitu pernyataan nomor satu dengan jumlah 189 dan presentase $4,02 \%$ berada pada range skor tinggi, karena pegawai selalu bekerja dengan disiplin yang tinggi demi tercapainya tujuan perusahaan. Untuk rata-rata skornya sebesar $4,01 \%$ dan berada pada range skor tinggi.

Tabel 12.Frekuensi dan Persentase Tanggapan Responden Untuk Indikator Tanggung Jawab

\begin{tabular}{|c|c|c|c|c|c|c|c|c|c|}
\hline \multirow[b]{2}{*}{ NO } & \multirow[b]{2}{*}{ Tanggung Jawab } & \multicolumn{5}{|c|}{ Jawaban } & \multirow[b]{2}{*}{ Skor } & \multirow[b]{2}{*}{$\begin{array}{l}\text { Rata- } \\
\text { rata }\end{array}$} & \multirow[b]{2}{*}{ Ket. } \\
\hline & & $\begin{array}{l}\text { STS } \\
(1)\end{array}$ & $\begin{array}{l}\text { TS } \\
(2)\end{array}$ & $\begin{array}{l}\mathbf{R r} \\
\text { (3) }\end{array}$ & $\begin{array}{c}S \\
(4)\end{array}$ & $\begin{array}{l}\text { SS } \\
(5)\end{array}$ & & & \\
\hline 1 & $\begin{array}{l}\text { Pegawai terdorong untuk } \\
\text { menyelesaikan pekerjaan }\end{array}$ & 0 & 0 & 4 & 29 & 14 & 198 & 4,21 & $\begin{array}{l}\text { Sangat } \\
\text { Tinggi }\end{array}$ \\
\hline
\end{tabular}




\begin{tabular}{|c|l|l|l|l|l|l|l|l|l|}
\hline & $\begin{array}{l}\text { dengan tuntas tanpa } \\
\text { adanya penundaan }\end{array}$ & & & & & & & \\
\hline 2 & $\begin{array}{l}\text { Pegawai selalu berusaha } \\
\text { bekerja dengan baik dan } \\
\text { tepat waktu }\end{array}$ & 0 & 1 & 4 & 25 & 17 & 209 & 4,47 & $\begin{array}{l}\text { Sangat } \\
\text { Tinggi }\end{array}$ \\
\hline 3 & $\begin{array}{l}\text { Pegawai selalu berusaha } \\
\text { memberikan hasil yang } \\
\text { berkualitas bagi instansi }\end{array}$ & 0 & 0 & 8 & 24 & 15 & 195 & 4,15 & $\begin{array}{l}\text { Sangat } \\
\text { Tinggi }\end{array}$ \\
\hline \multicolumn{7}{|c|}{ Jumlah } \\
\hline
\end{tabular}

Sumber : Data diolah (2019)

Dari Tabel 12 di atas, dapat diketahui bahwa persepsi responden terhadap variabel kinerja pegawai mengenai indikator tanggung jawab dengan pernyataan tertinggi yaitu pernyataan nomor dua dengan jumlah 209 dan presentase $4,47 \%$ berada pada range skor sangat tinggi, karena pegawai selalu berusaha bekerja dengan baik dan tepat waktu. Untuk rata-rata skornya sebesar $4,26 \%$ dan berada pada range skor sangat tinggi.

Tabel 13. Frekuensi dan Persentase Tanggapan Responden Mengenai Indikator Disiplin

\begin{tabular}{|c|c|c|c|c|c|c|c|c|c|}
\hline \multirow[b]{2}{*}{ NO } & \multirow[b]{2}{*}{ Disiplin } & \multicolumn{5}{|c|}{ Jawaban } & \multirow[b]{2}{*}{ Skor } & \multirow{2}{*}{$\begin{array}{c}\text { Rata- } \\
\text { rata } \\
\text { skor }\end{array}$} & \multirow[b]{2}{*}{ Ket. } \\
\hline & & $\begin{array}{c}\text { STS } \\
\text { (1) }\end{array}$ & $\begin{array}{l}\text { TS } \\
\text { (2) }\end{array}$ & $\begin{array}{l}\mathbf{R r} \\
\text { (3) }\end{array}$ & $\begin{array}{c}\text { S } \\
(4)\end{array}$ & $\begin{array}{l}\text { SS } \\
\text { (5) }\end{array}$ & & & \\
\hline 1 & $\begin{array}{l}\text { Pegawai berusaha } \\
\text { menyelesaikan pekerjaan } \\
\text { sesuai standar yang telah } \\
\text { ditetapkan kantor. }\end{array}$ & 0 & 5 & 4 & 32 & 6 & 180 & 3,83 & Tinggi \\
\hline 2 & $\begin{array}{l}\text { Pegawai membuang- } \\
\text { buang waktu dalam } \\
\text { bekerja dengan kegiatan } \\
\text { yang lama. }\end{array}$ & 0 & 10 & 4 & 26 & 7 & 171 & 3,64 & Tinggi \\
\hline 3 & $\begin{array}{l}\text { Pegawai selalu } \\
\text { menyelesaikan tugas- } \\
\text { tugas dengan tepat waktu } \\
\text { dan mengutamakan } \\
\text { prinsip efisiensi }\end{array}$ & 7 & 23 & 6 & 6 & 5 & 130 & 2,77 & Cukup \\
\hline \multicolumn{7}{|c|}{ Jumlah } & 481 & 10,23 & \\
\hline \multicolumn{8}{|c|}{ Rata-rata } & 3,41 & Tinggi \\
\hline
\end{tabular}

Sumber : Data diolah (2019)

Dari Tabel 13 di atas, dapat diketahui bahwa persepsi responden terhadap variabel kinerja pegawai mengenai indikator disiplin dengan pernyataan tertinggi yaitu pernyataan nomor satu dengan jumlah 180 dan presentase 3,83\% berada pada range skor tinggi, karena pegawai berusaha menyelesaikan pekerjaan sesuai standar yang telah ditetapkan kantor. Untuk rata-rata skornya sebesar 3,41\% dan berada pada range skor tinggi.

Tabel 14. Frekuensi Dan Persentase Tanggapan Responden Mengenai Indikator Inisiatif

\begin{tabular}{|c|c|c|c|c|c|c|c|c|c|c|}
\hline \multirow[b]{2}{*}{ NO } & \multirow{2}{*}{\multicolumn{2}{|c|}{ Inisiatif }} & \multicolumn{5}{|c|}{ Jawaban } & \multirow[b]{2}{*}{ Skor } & \multirow{2}{*}{$\begin{array}{c}\text { Rata- } \\
\text { rata } \\
\text { skor }\end{array}$} & \multirow[b]{2}{*}{ Ket. } \\
\hline & & & $\begin{array}{l}\text { STS } \\
\text { (1) }\end{array}$ & $\begin{array}{l}\text { TS } \\
(2)\end{array}$ & $\begin{array}{l}\mathbf{R r} \\
\text { (3) }\end{array}$ & $\begin{array}{l}S \\
(4)\end{array}$ & $\begin{array}{l}\text { SS } \\
(5)\end{array}$ & & & \\
\hline 1 & $\begin{array}{l}\text { Pegawai } \\
\text { memberikan ide }\end{array}$ & $\begin{array}{l}\text { mampu } \\
\text { kreatif }\end{array}$ & 3 & 19 & 9 & 11 & 5 & 137 & 2,91 & $\begin{array}{l}\text { Cukup } \\
\text { Tinggi }\end{array}$ \\
\hline
\end{tabular}




\begin{tabular}{|c|l|l|l|l|l|l|l|l|l|}
\hline & untuk kemajuan perusahaan & & & & & & & & \\
\hline 2 & $\begin{array}{l}\text { Pegawai selalu berusaha } \\
\text { menyelesaikan masalah } \\
\text { pekerjaan tanpa menunggu } \\
\text { perintah atasan }\end{array}$ & 4 & 15 & 8 & 15 & 5 & 143 & 3,04 & $\begin{array}{c}\text { Cukup } \\
\text { Tinggi }\end{array}$ \\
\hline 3 & $\begin{array}{l}\text { Pegawai diberikan } \\
\text { kesempatan melakukan } \\
\text { inovasi dalam pekerjaan } \\
\text { yang berisiko. }\end{array}$ & 5 & 21 & 5 & 10 & 6 & 132 & 2,81 & $\begin{array}{c}\text { Cukup } \\
\text { Tinggi }\end{array}$ \\
\hline \multicolumn{7}{|c|}{ Jumlah } \\
\hline Rata-rata
\end{tabular}

Sumber : Data diolah (2019)

Dari Tabel 14 di atas, dapat diketahui bahwa persepsi responden terhadap variabel kinerja pegawai mengenai indikator inisiatif dengan pernyataan tertinggi yaitu pernyataan nomor dua dengan jumlah 143 dan presentase 3,04\% berada pada range skor cukup tinggi, karena pegawai selalu berusaha menyelesaikan masalah pekerjaan tanpa menunggu perintah atasan. Untuk rata-rata skornya sebesar $2,92 \%$ dan berada pada range skor cukup tinggi.

Tabel 15.Kesimpulan rata-rata tanggapan responden terhadap indikator dari variabelKinerja Pegawai.

\begin{tabular}{|c|l|c|c|c|}
\hline No & \multicolumn{1}{|c|}{ Indikator } & Jumlah Skor & Rata-Rata & Ket \\
\hline 1 & Efektivitas & 565 & 4,01 & Tinggi \\
\hline 2 & Tanggung Jawab & 602 & 4,26 & Sangat Tinggi \\
\hline 3 & Disiplin & 481 & 3,41 & CukupTinggi \\
\hline 4 & Inisiatif & 412 & 2,92 & CukupTinggi \\
\hline
\end{tabular}

Sumber : Data diolah (2019)

Berdasarkan tabel 15 kesimpulan rata-rata tanggapan responden terhadap indikator dari kinerja pegawai diatas dapat dilihat bahwa indikator dengan jumlah skor tertinggi 602 berdasarkan jawaban responden adalah tanggung jawab dengan rata-rata skor 4,26. Hal tersebut menunjukan bahwa tanggung jawab berpengaruh kuat dalam hal mempengaruhi kinerja pegawai pada kantor Kecamatan Walenrang Utara Kabupaten Luwu. Pada tabel diatas juga dapat dilihat inisiatif dengan jumlah skor terendah yaitu 412 dengan skor rata-rata 2,92, hal ini menunjukkan indikator inisiatif perlu ditingkatkan lagi.

\section{Uji Validitas dan Uji Reabilitas}

Berdasarkan hasil analisis uji validity dan reability variabel penelitian menggunakan SPSS 20 menunjukkan bahwa penelitian pengujuan validitas dan reabilitas terhadap instrumen kuesioner dilakukan untuk menjamin bahwa instrument penlitian yang digunakan tersebut akurat dan dapat dipercaya, serta dapat diandalkan apabila digunakan sebagai alat dalam mengumpulkan data, untuk jelasnya kedua pengujian tersebut dapat dijelaskan sebagia berikut:

\section{a. Uji Validitas}

Uji validitas digunakan untuk menguji sejauh mana ketepatan alat pengukur dapat mengungkapkan konsep gejala atau kejadian yang diukur. Uji validitas digunakan untuk mengukur sah atau tidaknya suatu kuesioner, suatu kuesioner dikatakan valit jika pertanyaan pada kuesioner mampu untuk mengungkapkan sesuatu yang dapat diukur oleh kuesioner tersebut. Uji validitas dihitung dengan membandingkan nilai $r$ hitung (correlated item-total 
correlation) dengan nilai $\mathrm{r}$ tabel, $\mathrm{r}$ hitung $>$ dari $\mathrm{r}$ tabel, maka pernyataan tersebut dinyatakan valit.

Dari hasil uji validitas menggunkan SPSS, Tabel correlations variabel $\mathrm{x}$ dan $\mathrm{y}$, dapat kita lihat pada kolom Corrected Item-Total Correlation di mana untuk setiap item pernyataan tentang variabel stress kerja dari 15 item pernyataan ada 1 pernyataan dinyatakan tidak valid karena memiliki korelasi yang lebih kecil dari batasan minimum r yaitu $0,30(0,217<0,30)$ yaitu pada pernyataan ke 14 pada indikator kepemimpinan organisasi, selebihnya 14 pernyataan lainnya dinyatakan valid karena memiliki korela yang lebih besar dari batasan minimum $r$ yaitu 0,30 dan variabel kinerja pegawai sebanyak 12 item pernyataan dinyatakan valid karena memiliki korelasi yang lebih besar dari batasan minimum $r$ yaitu 0,30.

b. Uji Reabilitas

Uji Validitas adalah alat untuk mengukur kuesioner yang merupakan indikor dari variabel. Suatu koesioner dikatakan reliabel atau handal jika jawaban seseorang terhadap pernyataan adalah konsisten atau stabil dari waktu ke waktu. Pengujian reabilitas dalam penelitian ini adalah dengan menggunakan rumus alpha.

Dalam penelitian ini, uji reabilitas dilakukan dengan melihat hasil prhitungan nilai cronbach alpha (a). Suatu variabel dikatakan reliabel jika memberilan nilai cronbach alpha (a) $>0,6$ yaitu jika dilakukan penelitian ulang dengan waktu dan variabel yang berbeda akan menghasilkan hasil kesimpulan yang sama. Tetapi sebaliknya bila alpha $(a)<0,6$ maka dianggap kurang handal, artiya bila variabel-variabel tersebut dilakuakn penelitian ulang dengan waktu yang berbeda. Adapun hasil olahan data mengenai realibilitas dapat dilihat pada.

Tabel 16.Pengujuan Hasil Reliabilitas Variabel Stres Kerja (X) dan Kinerja Pegawai (Y).

Reliability Statistics

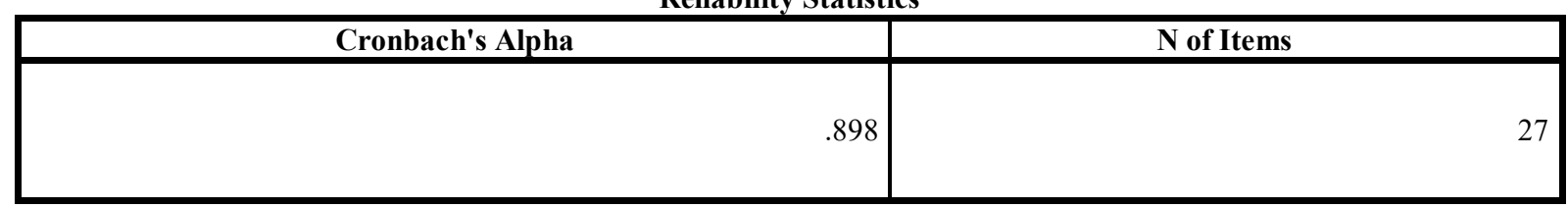

Sumber : Data diolah (2019) melaluai SPSS V.20

Dari tabel 16 realibility statistics di atas, diperoleh nilai cronbach's alpha sebesar 0,898 dengan jumlah item sebanyak 27 pernyataan. Hal ini membuktikan bahwa pernyataan tentang stres kerja dan kinerja pegawai adalah baik atau realibel karena nilai cronbach's alpha lebih dari 0,60 .

\section{Analisis Regresi Linier Sederhana}

Analisis regresi linear sederhana yaitu suatu metode yang digunakan untuk menentukan ketepatan prediksi dari pengaruh yang terjadi antara variabel independen atau konpensasi terhadap variabel dependen produktivitas kerja. Perhitungan statistik dalam analisis regresi linear sederhana yang digunakan dalam penelitian ini adalah dengan menggunakan bantuan program komputer SPSS Versi 20.

Tabel 17. Hasil Analisis Regresi Linier Sederhana

Coefficients $^{\mathrm{a}}$

\begin{tabular}{|c|c|c|c|c|c|c|}
\hline \multirow{2}{*}{\multicolumn{2}{|c|}{ Model }} & \multicolumn{2}{|c|}{ Unstandardized Coefficients } & Standardized & \multirow[t]{2}{*}{$\mathrm{T}$} & \multirow[t]{2}{*}{ Sig. } \\
\hline & & B & Std. Error & Beta & & \\
\hline \multirow{2}{*}{1} & (Constant) & .464 & 5.991 & & .078 & .939 \\
\hline & $\mathrm{X}$ & 694 & .097 & .731 & 7.187 & .000 \\
\hline
\end{tabular}

a. Dependent Variable: $Y$

Sumber : Data Diolah (2018) Melalui Spss V.20 
Berdasarkan hasil analisis regresi linier sederhana, untuk menganalisi pengaruh stres kerja terhadap kinerja pegawai kantor Kecamatan Walenrang Utara Kabupaten Luwu dengan menggunakan rumus yang dikutip dari buku Priyatno (2008) yaitu :

$$
\mathrm{Y}=0,464+0,694 \mathrm{X}
$$

Keterangan :

$\mathrm{Y}=$ Variabel Dependen (kinerja pegawai)

$\alpha=$ Nilai Konstanta

$\mathrm{x}=$ Variabel Independen (stres kerja)

b $=$ Koefisien Regresi

Persamaan regresi dapat dijelaskan sebagia berikut :

1. Konstanta sebesar 0,464 artinya jika stres kerja nilainya 0 , maka kinerja pegawai pada kantor Kecamatan Walenrang Utara Kabupaten Luwu tetap yaitu 0,464.

2. Koefisien regresi variabel stres kerja sebesar 0,694 artinya jika stres kerja pada kantor Kecamatan Walenrang Utara Kabupaten Luwu mengalami kenaikan 1 satuan, maka kinerja karyawan akan mengalami peingkatan sebesar 0,694. Koefisien bernilai positif antara stres kerja dengan kinerja pegawai, maka semakin tinggi stres kerja yang diberikan kepada pegawai maka kinerja pegawai akan semakin tinggi atau semakin baik.

\section{a. Uji Parsial (Uji T)}

Uji t pada dasarnya menunjukan seberapa jauh pengaruh satu variable penjelas atau bebas secara individual dalam menerangkan variasi variable terikat. Pengujian ini bertujuan untuk menguji pengaruh variable bebas (stres kerja) terhadap variable terikat (kinerja karyawan) secara terpisah atau parsial.

$$
\begin{aligned}
\mathrm{df} \quad & =\mathrm{n}-\mathrm{k}-1 \\
& =47-2-1 \\
& =44, \text { maka diperoleh } \mathrm{T}_{\text {tabel yaitu } 2,011}
\end{aligned}
$$

Dari tabel 15 hasil uji SPSS menunjukkan bahwa X (stres kerja) terhadap variabel Y (kinerja pegawai) diperoleh Nilai $T_{\text {hitung }}$ untuk variabel stres kerja $(X)$ sebesar 7,187 > nilai $\mathrm{T}_{\text {tabel }}$ yaitu 2,011 dan signifikansi sebesar $0,000<0,05$, dengan tingkat signifikan 0,000 , dimana tingkat signifikan lebih rendah dari 0,05 . Hal ini berarti stres kerja berpengaruh secara signifikan terhadap kinerja pegawai karena nilai singnifikan lebih rendah dari 0,05 , jadi dapat disimpulkan bahwa data variabel stres kerja berpengaruh secara signifikan terhadap kinerja pegawai pada kantor Kecamatan Walenrang Utara Kabupaten Luwu.

\section{b. Uji Koefisien Determinasi $\left(\mathbf{R}^{2}\right)$}

Uji koefisien determinasi digunakan untuk mengukur seberapa jauh kemampuan model dalam menerangkan variasi (Priyatno,2008), Nilai $R^{2}$ yang semakin mendekati 1 berarti variable independen memberikan hampir semua informasi yang dibutuhkan untuk memprediksi variable dependen. Koefisien determinasi yang digunakan adalah nilai Adjusted $R$ square karena lebih dapat dipercaya dalam mengevaluasi model regresi. Nilai Adjusted $R$ square dapat naik atau turun apabila satu variable independen ditambahkan kedalam model.

Tabel 16. Hasil Analisis Uji Koefisien Determinasi $\left(R^{2}\right)$

Model Summary

\begin{tabular}{|l|r|r|r|r|}
\hline Model & \multicolumn{1}{|c|}{ R } & \multicolumn{1}{|c|}{ R Square } & Adjusted R Square & Std. Error of the Estimate \\
\hline 1 & $.731^{\mathrm{a}}$ & .534 & .524 & 4.40018 \\
\hline
\end{tabular}

a. Predictors: (Constant), VAR00001

Sumber : Data Diolah (2018) Melalui Spss V.20 
Dari Tabel Model Summary di atas diketahui nilai $R$ Square $\left(R^{2}\right)$ sebesar 0,534 berarti bahwa variabel stres kerja berpengaruh sebesar 53,4\% terhadap kinerja karyawan kantor Kecamatan Walenrang Utara Kabupaten Luwu, dan sisanya 46,6\% dipengaruhi oleh faktor lain yang tidak diteliti dalam penelitian ini.

\section{Pembahasan}

Hasil pengujian secara umum terhadap variabel stres kerja menunjukkan pengaruh secara signifikan dan positif terhadap kinerja pegawai kantor Kecamatan Walenrang Utara Kabupaten Luwu.

Regresi linear sederhana koefisien regresi variabel stres kerja dengan sebesar 0,694 artinya jika stres kerja pada kantor Kecamatan Walenrang Utara Kabupaten Luwu mengalami kenaikan 1 satuan, maka kinerja karyawan akan mengalami penigkatan sebesar 0,694. Koefisien bernilai positif antara stres kerja dengan kinerja pegawai, maka semakin tinggi stres kerja yang diberikan kepada pegawai maka kinerja pegawai akan semakin tinggi atau semakin baik.

Dari hasil uji parsial (Uji t) menunjukkan bahwa X (stres kerja) terhadap variabel Y (kinerja pegawai) diperoleh Nilai $T_{\text {hitung }}$ untuk variabel stres kerja $(\mathrm{X})$ sebesar 7,187 $>$ nilai $\mathrm{T}_{\text {tabel }}$ yaitu 2,011 dan signifikansi sebesar $0,000<0,05$, dengan tingkat signifikan 0,000 , dimana tingkat signifikan lebih rendah dari 0,05 . Hal ini berarti stres kerja berpengaruh secara signifikan terhadap kinerja pegawai karena nilai signifikan lebih rendah dari 0,05 , jadi dapat disimpulkan bahwa data variabel stres kerja berpengaruh secara signifikan terhadap kinerja pegawai pada kantor Kecamatan Walenrang Utara Kabupaten Luwu. Dari hasil uji determinasi nilai $R$ Square $\left(R^{2}\right)$ sebesar 0,534 berarti bahwa variabel stres kerja berpengaruh sebesar 53,4\% terhadap kinerja pegawai kantor Kecamatan Walenrang Utara Kabupaten Luwu, dan sisanya $46,6 \%$ dipengaruhi oleh faktor lain yang tidak diteliti dalam penelitian ini.

\section{SIMPULAN DAN SARAN}

\section{Simpulan}

Berdasarkan hasil pengujian data penelitian diketahui bahwa ada pengaruh signifikan stres kerja terhadap kinerja pegawai kantor Kecamatan Walenrang Utara Kabupaten Luwu. Dilihat dari hasil nilai $\mathrm{T}_{\text {hitung }}$ sebesar 7,187 $>$ nilai $\mathrm{T}_{\text {tabel }}$ yaitu 2,011 dan signifikansi sebesar $0,000<0,05$, dikuatkan oleh nilai $R$ Square $\left(R^{2}\right)$ sebesar 0,534 berarti bahwa variabel stres kerja berpengaruh sebesar $53,4 \%$ terhadap kinerja karyawan.

\section{Saran}

Berdasarkan hasil dan simpulan yang diperoleh dalam penelitian ini, maka diajukan saran-saran sebagai pelengkap terhadap hasil penelitian yang dapat diberikan sebagai berikut:

1. Kepala Kantor Kecamatan Walenrang Utara Kabupaten Luwu hendaknya lebih memperhatikan interaksi yang harmonis antar semua pegawai, agar terjadi komunikasi dua arah yang lebih kondusif agar terjadi ketenangan dalam bekerja.

2. Kepada semua pegawai pada kantor Kecamatan Walenrang Utara Kabupaten Luwu agar tidak menunda-nunda pekerjaan, tetapi harus sesuai dengan SOP yang ada.

3. Kepala Kantor Kecamatan Walenrang Utara Kabupaten Luwu hendaknya memberi tugas pekerjaan sesuai dengan kemampuan dan keahlian setiap pegawai, agar tidak merasa terlalu berat pekerjaan yang mereka kerjakan.

\section{DAFTAR PUSTAKA}

AA. Mangkunegara, (2000), Manajemen Sumber Daya Manusia. Perusahaan, Cetakan Ke-2, PT. Remaja Rosda Karya, Bandung. 
Brahmasari dan Suprayetno. (2008). Pengaruh motivasi Kerja, Kepemimpinan dan. Budaya Organisasi Terhadap Kepuasan Kerja Karyawan serta Dampaknya.

Gibson, James L. (2007). Organisasi. Jakarta: Erlangga.

Hariandja, Marihot Tua Effendi. (2005). Manajemen Sumber Daya Manusia. Cetakan Pertama. Jakarta: PT. Gramedia Widasarana Indonesia.

Irwan, I., \& Haryono, D. (2015). Pengendalian Kualitas Statistik (Pendekatan Teoritis dan Aplikatif). Bandung: Alfabeta

Mangkunegara, A.P. (2009). Prilaku dan Manajemen Organisasi. PT. Erlangga, Jakarta.

Mahsun, Mohamad, (2004). Pengukuran Kinerja Sektor Publik, Penerbit BPFE, Yogyakarta.

Malayu Hasibuan, (2000). Mangkunegara, A.P. 2008. Prilaku dan Manajemen Organisasi. PT. Erlangga, Jakarta.

Malayu Hasibuan,. (2000). Manajemen Sumber Daya Manusia. Edisi. Revisi.Jakarta: PT Bumi Aksara

Purwanto, Suharyadi. (2003). Statistika untuk Ekonomi dan Keuangan Modern. Salemba Empat, Jakarta

Rivai, Veithzal. (2004). Manajemen Sumber Daya Manusia Untuk Perusahaan. PT Raja Grafindo Persada, Jakarta.

Robbins, S.P. (2001). Psikologi organisasi, (Edisi ke-8). Jakarta: Prenhallindo.

Robbins, S.P. (2006). Perilaku Organisasi: Konsep, Kontroversi dan Aplikasi. Jakarta: Pearson Education Asia Pte Ltd dan PT Prenhallindo.

Suharyadi dan Purwanto, S. K. (2004). Statistika Dasar. Jakarta: Salemba Empat.

Umar (2003). Riset Pemasaran dan Perilaku Konsumen. Jakarta: Gramedia. 